\title{
In vivo effects of metaldehyde on Pacific oyster, Crassostrea gigas: comparing hemocyte parameters in two oyster families
}

\author{
Pierrick Moreau ${ }^{1}$, Thierry Burgeot ${ }^{2}$, Tristan Renault ${ }^{1}$ *
}

1. Unité Santé Génétique et Microbiologie des Mollusques, Laboratoire de Génétique et Pathologie des Mollusques Marins, Ifremer (Institut Français de Recherche pour l'Exploitation de la Mer), Ronce les Bains, 17390, La Tremblade, France

2. Research Unit of Biogeochemistry and Ecotoxicology, Ifremer (Institut Français de Recherche pour l'Exploitation de la Mer), Rue de l'lle d'Yeu, BP 21105, 44311, Nantes, France

*: Corresponding author : Tristant Renault, email address : tristan.renault@ifremer.fr

\begin{abstract}
:
Pollutants via run-off into the ocean represent a potential threat to marine organisms, especially bivalves such as oysters living in coastal environments. These organisms filter large volumes of seawater and may accumulate contaminants within their tissues. Pesticide contamination in water could have a direct or indirect toxic action on tissues or cells and could induce alteration of immune system. Bivalve immunity is mainly supported by hemocytes and participates directly by phagocytosis to eliminate pathogens. Some studies have shown that pesticides can reduce immune defences and/or modify genomes in vertebrates and invertebrates. Metaldehyde is used to kill slugs, snails and other terrestrial gastropods. Although metaldehyde has been detected in surface waters, its effects on marine bivalves including the Pacific oyster, Crassostrea gigas, have never been studied. Given the mode of action of this molecule and its targets (molluscs), it could be potentially more toxic to oysters than other pesticides (herbicides, fungicides, insecticides, etc.). Effects of metaldehyde on oyster hemocyte parameters were thus monitored through in vivo experiments based on a short-term exposure. In this work, metaldehyde at $0.1 \mu \mathrm{g} / \mathrm{L}$, which corresponds to an average concentration detected in the environment, modulated hemocyte activities of Pacific oysters after an in vivo shortterm contact. Individuals belonging to two families showed different behaviours for some hemocyte activities after contamination by metaldehyde. These results suggested that effects of pollutants on oysters may differ from an individual to another in relation to genetic diversity. Finally, it appears essential to take an interest in the effects of metaldehyde on a wide variety of aquatic invertebrates including those that have a significant economic impact.
\end{abstract}

Keywords: Immunity ; Hemocytes ; Metaldehyde ; Pacific oyster ; Flow cytometry ; In vivo ; Genetic diversity 


\section{Introduction}

Coastal areas represent constantly changing environments and often are populated by abundant living communities. The relationship between river flow, inputs of organic matter and nutrients and estuarine primary production are well known. The importance of pollution of these areas by various toxic compounds has been proved (His et al., 1999; Jacquet et al., 2012). France is one of the first European users of pesticides for agriculture purposes and many of these molecules are found in the French coastal waters. Among the different pesticides found (herbicides, fongicides, insecticides, etc.) during detection campaigns, molluscicides including metaldehyde were also detected in surface waters (Les pesticides dans les eaux superficielles bretonnes - bilan 2010 du réseau Corpep, 2011). Metaldehyde (2,4,6,8-tetramethyl1,3,5,7-tetraoxocanemetacetaldehyde) is an organic compound with the formula (CH3CHO)4. Metaldehyde is used to kill slugs, snails and other terrestrial gastropods. It acts on the mucocytes of the salivary and epidermis glands. It induces lesions of cell membranes and irreversible damages of mitochondria and nuclei (Nielsen, 1988 ). These actions make it impossible for the gastropods to rehydrate themself. Soon as ingestion or contact with metaldehyde, the animal stops feeding. Death occurs in 6 hours in dry conditions and 24 hours in wet conditions (Nielsen, 1988 ). Methaldehyde traitment used in slug and snail control in agricultural crops acts by causing irreversible damage to mucous cells of the skin and gut lining, leading to

excessive mucus production, destruction of the mucous cells, damage to the absorptive cells of hepatopancreas and ultimately to death (Triebskorn et al., 1996). Although metaldehyde is forbidden in biological farming since 2006, it could be detected at concentrations of about $0.1 \mu \mathrm{g} / \mathrm{L}$ in 2010 and 2011 in the aquatic environment (Les pesticides dans les eaux superficielles bretonnes - bilan 2010 du réseau Corpep, 2011). Zhang et al. (2011) reported the half-life of metaldehyde in soil was about 4 days, but there is no data about half-life in the water.

While there are many examples of relationships which can exist between pollution and increased susceptibility to infectious diseases in mammals and vertebrates, few work has been done in invertebrates (Gagnaire et al., 2007). Mass mortality outbreaks of Pacific oyster, Crassostrea gigas, spat observed since 2008 in France related to ostreid herpesvirus 1 (OsHV-1) infection (Segarra et al., 2010) can leave suspect the quality of the marine environment (Renault, 2011) and a role of pesticides with a seasonal use and the arrival of fresh waters in the estuarine areas during spring (Burgeot et al., 2008). In this context, the Pacific 
oyster appaears as a species of interest to define the importance of the immune system as a target of pollutants in invertebrates and mainly molluscicides in bivalves. Although metaldehyde has been detected in surface waters and is known to be toxic for terrestrial and aquatic gasteropods including snails (Dai et al. 2011), its effects on marine bivalves including the Pacific oyster, C. gigas, have never been studied. Oysters as marine mollusc could be exposed after application in a cultural or a domestic area. Metaldehyde is mainly known for food poisoning in mammals. Dogs, cattle, horses and wild lagomorphs are the species most often poisoned by metaldehyde (Campbell. 2008; Mills. 2008; Bates et al., 2012; Tawde et al., 2012). Effects of metaldehyde on oyster hemocyte parameters were thus monitored through in vivo experiments based on a short term exposure. Pacific oyster were incubated with metaldehyde for a $24 \mathrm{~h}$ period and hemolymphs were collected from the adductor muscle sinus after contamination. Oysters belonging to two bi-parental families produced in the same conditions were used in the present study in order to explore relationship between genetics and pollutant susceptibility. In order to reveal potential effects of metaldehyde, hemocyte parameters including dead/alive cells, non-specific esterase activities, and phagocytosis were monitored by flow cytometry. The purpose of this work relied on providing answers at two questions: (1) can metaldehyde at an environmental concentration affect hemocyte viability and activities in the Pacific oyster after a short exposure? (2) could it be possible to show a relationship between susceptibility to the pollutant and oyster genetic diversity ? 


\section{Materials and methods}

Pacific oysters

Within the framework of the European project Bivalife (FP7, 2011-2014), bi-parental families of Pacific oysters, Crassostrea gigas, were produced at Ifremer's facilities (La Tremblade, Charente Maritime, France) in order to obtain biological material presenting contrasted susceptibility to different pathogens including OsHV-1. Two of the bi-parental families were selected on the basis of their susceptibility to the viral infection (OsHV-1) in experimental conditions. Family 32 presented moderate mortality rates (around 30\%) and family 29 presented high mortality rates (around 86\%) 5 days after experimental OsHV-1 infection. These families has been previously used to explore pesticide susceptibilty of $C$. gigas hemocytes (Moreau et al., 2014). For both families animals were 11 month old at the time of experiments.

\section{Metaldehyde}

Metaldehyde was purchased from Supelco (Sigma-Aldrich). Solvent (methanol) was used as recommended by the manufacturer and it concentration was less than $0.5 \%$ in order to avoid disturbance of hemocyte parameters.

\section{Experimental design}

Assays were carried out to study the effects of metaldehyde in vivo on Pacific oysters belonging to families 32 and 29, following different hemocyte parameters by flow cytometry: cell size and complexity, hemocyte mortality, non-specific esterase activities and phagocytic activity. Concentrations tested $(0.1 \mu \mathrm{g} / \mathrm{L}$ or $1 \mathrm{X})$ corresponded to an average concentration reported in the aquatic environment.

Pacific oysters were incubated with metaldehyde during $24 \mathrm{~h}$. The water containing the pollutant in absence of algae was removed from the tanks after a 24h period incubation. After the 24h contact with the pollutant, oysters were maintained in absence of metaldehyde for 48 hours in order to collect samples at different time points. Oysters were fed with Chaetoceros gracialis ( $3 \times 10^{9}$ cells per tank). Water was changed at Day 1 (24h), day 2 (48h) and day 3 (72h). Temperature of seawater in tanks was maintained between $19.5^{\circ} \mathrm{C}$ and $20^{\circ} \mathrm{C}$ during the experiment. Hemolymphs were collected at $24 \mathrm{~h}, 48 \mathrm{~h}$ and $72 \mathrm{~h}$. Four tanks were used in these experiments: 2 tanks with metaldehyde treatment and 2 tanks without metaldehyde treatment receiving the same quantity of solvent used for testing metaldehyde (the solvent was added in the water: 
negative controls). A pool of filtered hemolymphs was prepared for each tank from 5 oysters at each time of collection (24h, 48h and 72h). The experiment was repeated three times for both families.

\section{Hemocyte collection}

Pacific oyster hemolymph was withdrawn from the adductor muscle sinus, with the use of $1 \mathrm{ml}$ syringue equipped with a needle $(0.9 \times 25 \mathrm{~mm})$ after breaching the shell using pincer. Hemolymph samples were filtered on a $60 \mu \mathrm{m}$ mesh to eliminate debris. Hemocytes were counted using a Malassez cell. Cells from 5 oysters per tank (2 tanks with metaldehyde treatment and 2 tanks without metaldehyde treatment) were pooled in order to manage inter-individual variations and to provide enough hemocytes to carry out experiments. Hemocytes were kept on ice until use to avoid cell aggregation.

\section{Flow cytometry}

Oyster hemocyte activities were monitored using flow cytometry (EPICS ${ }^{\circledR}$ XL flow cytometer, Beckman Coulter) and counting 5000 events. Cell cytograms showed cell size (FSC value) and cell complexity (SSC value) and the fluorescence channel(s) corresponding to the marker used. A gate was defined on the basis of FSC value in order to eliminate cell debris. To measure hemocyte mortality, $200 \mu \mathrm{L}$ of hemolymph were incubated with $10 \mu \mathrm{L}$ of propidium iodide for 30 min on ice in the dark (Gagnaire et al., 2003; Moreau et al., 2014). Non-specific esterase activities were investigated in $200 \mu \mathrm{L}$ of hemolymph after 30 min incubation in the dark at room temperature with $1 \mu \mathrm{L}$ of FDA (fluorescein diacetate) (Gagnaire et al., 2003; Moreau et al., 2014). Lastly, the phagocytic activity was followed in $200 \mu \mathrm{L}$ of hemolymph supplemented with $10 \mu \mathrm{L}$ of fluorescent beads $1 \mu \mathrm{m}$ in diameter (ratio bead / hemocyte: 700/1) with a 2 hour incubation

in the dark at room temperature. Cell size and complexity were measured in $200 \mu \mathrm{L}$ of hemolymph incubated for $30 \mathrm{~min}$ in the dark at room temperature without any treatment (Gagnaire et al., 2003; Moreau et al., 2014).

\section{Statistical analysis}

Results were expressed as percentage of labelled cells. Statistical analysis was performed using the Wilcoxon - Mann Whitney test by statistical software R, to compare two groups. The Kruskal-Wallis test was used to compare more than two groups. Significance was set at $\mathrm{p} \leq 0.05\left(^{*}\right)$ and at $\mathrm{p} \leq 0.01\left({ }^{* * *}\right)$. 


\section{Results}

A preliminary experiment was carried out using two concentrations of metaldehyde $(0,1 \mu \mathrm{g} / \mathrm{L}(1 \mathrm{x})$ and 1 $\mu g / L(10 x)$ ). Similar results were reported for both tested concentrations (data not shown). The lowest concentration was selected in the present study in order to represent the average concentration found in the environment (mainly surface water and groundwater).

For the family 32, significant differences were observed between negative controls and metaldehyde treatement for hemocyte mortality. Although no significant difference was reported between treatments at $24 \mathrm{~h}$, at $48 \mathrm{~h}$ cell mortality was significantly higher in presence of metaldehyde: $8.04 \% \pm 0.48 \%$ for negative control and $10.87 \% \pm 0.34 \%$ for metaldehyde treatment (Figure 1c). At $72 \mathrm{~h}$, cell mortality was also higher in presence of metaldehyde: $8.68 \% \pm 0.50 \%$ for negative control and $11.23 \% \pm 0.65 \%$ for metladehyde treatement (Figure 1c). For other activities tested, no significant differences were observed between both conditions (Figures 1a, 1b and 1d). For this family, the presence of metaldehyde at environmental concentration significantly increased hemocyte mortality at 48 hours $(\mathrm{p}<0,01)$ and 72 hours $(\mathrm{p}<0,05)$ after an exposure of 24 hours (Figure 1c).

Concerning the family 29, significant differences were observed between negative controls and metaldehyde treatment for hemocyte parameters. Although no significant differences in hemocyte mortality were observed for all sampling times (Figure 2c), differences were reported for cell size and complexity between negative controls and metaldehyde treatment, with a significant decrease of population 3 (interpreted as granulocytes) in the presence of metaldehyde at 24h and 48h (Figure 2a). At 72h, there was no more difference between both conditions. Regarding the non-specific esterase activities, a significant difference between negative controls and metaldehyde treatment was reported at 72 hours, with a significant reduction of the population presenting an intermediate level of non-specific esterase activities in presence of metaldehyde (Figure 2b). Finally, a significant difference $(\mathrm{p}<0.01)$ was observed for the phagocytic activity between both conditions, with a decrease of the activity in the presence of metaldehyde at 24 hours (Figure 2d). There was no difference at 48h and 72h (Figure 2d). 


\section{Discussion}

Metaldehyde at $0.1 \mu \mathrm{g} / \mathrm{L}$ which corresponds to an average concentration detected in the aquatic environment modulated hemocyte activities of Pacific oysters after an in vivo short term contact. Previous studies showed that hemocytes could have some level of resistance towards pesticides at high concentration in vitro (Gagnaire et al., 2003; Moreau et al., 2014). In the eastern oyster, Crassostrea virginica, reduced phagocytosis activity was observed after exposure to triforine (Alvarez and Friedl. 1992) and to the insecticide Chlordan at $250 \mu \mathrm{M}$ in vitro (Larson et al. 1989). Canty et al. (2007) reported a decrease in phagocytic index in the blue mussel, Mytilus edulis, after a short exposure to $0.1 \mathrm{mg} / \mathrm{L}$ azamethipos. Gagnaire et al. (2003) demonstrated also effects of pesticides on hemocytes of Pacific oysters for high concentrations. Moreover, metaldehyde at high concentrations showed no effects on C. gigas hemocytes in in vitro assays (Moreau et al., 2014). At a concentration of $1 \mathrm{~g} / \mathrm{L}$, metaldehyde did not affect Pacific hemocytes maintained in vitro (Moreau et al., 2014), whereas effects were reported in the present study at a concentration of $0.1 \mu \mathrm{g} / \mathrm{L}$. To understand possible adverse effects of pollutants, it appears most suited to develop in vivo assays as such assays integrate physiological processes than to use in vitro assays.

Individuals belonging to two families showed different behaviors for some hemocyte activities after contamination by metaldehyde. The increase of hemocyte mortality at $48 \mathrm{~h}(\mathrm{p}<0.01)$ and $72 \mathrm{~h}(\mathrm{p}<0.05)$ for the family 32, suggested a direct role of metaldehyde killing hemocytes in this family. A direct toxicity of metladehyde on cells was not observed for family 29. These observations suggested that metaldehyde could induce a decrease of the number of circulating immuno-competent cells, in family 32 and could reduce thus immune defenses through direct killing of hemocytes. It appears that Pacific oysters depending on their genetic diversity may present some differences in terms of susceptibility to metaldehyde as no increase of dead cells was reported for the family 29 in similar conditions. Concerning other hemocyte parameters (size and complexity, non-specific esterase activities and phagocytosis) metaldehyde demonstrated any effect on hemocytes of family 32. For family 29, metaldehyde had no direct effect on hemocyte mortality. However, other parameters were modulated by the presence of metaldehyde at $0.1 \mu \mathrm{g} / \mathrm{L}$. The results suggested that metaldehyde could have inhibitory effects on non-specific esterase activities. About the size and complexity, at $24 \mathrm{~h}(\mathrm{p}=0.01)$ and 48 hours $(\mathrm{p}<0.05)$ a decrease of population 3 interpreted as granulocytes was observed in the presence of metaldehyde suggesting a negative effect on granulocytes after a short term 
exposure. Granulocytes are cells that possess high phagocytic capacity and the decrease of this population could be related to the decrease in phagocytic activity $(\mathrm{p}<0.01)$ reported at $24 \mathrm{~h}$. Metaldehyde treatment was thus associated with a decrease of phagocytic activity at 24h, whereas there were no longer effects at $48 \mathrm{~h}$ and $72 \mathrm{~h}$, which suggested possible restoration of cellular functions either by acclimation and/or metabolization of metaldehyde. This type of transient effect face to stimulation in controlled conditions and recovery after some acclimatization time had already been observed in Lymnaea stagnalis for phagocytosis (Russo \& Lagadic. 2004). Other molecules also have effects on phagocytosis. Cooper \& Roch (2003) showed that Eisenia fetida phagocytosis was inhibited by carbaryl. In carp Cyprinus carpio, glyphosate has caused a decrease in phagocytic activity. Organochlorine pesticides such as DDT and lindane caused effects on the immune response in vertebrates by reducing phagocytosis, antibody production and increased susceptibility to diseases (Snieszko 1974; Dunier, 1991, Wong et al., 1992; Dunier \& Siwicki, 1993; Koner et al., 1998; Blakley et al., 1999). Phagocytosis can also be modulated in bivalves by dieldrin and chlordane (Anderson et al., 1981. Larson et al., 1989.). The effect of metaldehyde on phagocytic activity suggested that this molecule could act as an immunomodulator in the Pacific oysters rendering them more susceptible to infectious agents. Gagnaire et al. (2007) have demonstrated that the Pacific oysters were more susceptible to bacteria in the presence of pesticides. Oyster mortality was higher in pesticide-treated oysters compared to untreated ones after a bacterial challenge in experimental conditions. The expression of oyster genes was up-regulated in pesticide-treated oysters compared to untreated ones after the bacterial challenge (Gagnaire et al., 2007).

Results from the present study suggest that the genetic variability of animals needs to be taken into account when it is desired to test the effects of metaldehyde. Susceptibility to pollutants in the Pacific oyster and / or other bivalve species can be different and this could be explained by genetic variability that can exist within the same species. For example, a study showed there is variation in susceptibility to metaflumizone among 29 field populations of Plutella xylostella collected from 14 geographical locations in China (Khakame et al., 2013). Another study reported a comparison of two pre-adult groups of Parascaris equorum presenting different susceptibility to ivermectin and revealed difference in terms of SNPs detection and genes expression between groups of worms in presence of ivermectin (IVM). These results indicate that putatively resistance associated SNPs in populations with reduced IVM susceptibility could be 
identified. Recently, other studies have shown the relationship between genetic variability and sensitivity to pesticides. Uncovering SNP environment interactions can generate new hypotheses about the function of poorly characterized genetic variants and environmental factors, like pesticides (Koutros et al., 2013). This study suggests known genetic susceptibility loci may modify the risk between pesticide use and prostate cancer (Koutros et al., 2013).

The results of the present study showed that it is essential to take an interest in the effects of metaldehyde on a wide variety of non target aquatic organisms including those that have a significant economic impact. Experiments are continuing to investigate the effects of mixed pesticides (including metaldehyde) found in the environment on OsHV-1 experimental infection by following hemocyte parameters by flow cytometry and expression of immune related genes in the Pacific oysters by real-time PCR. Luna-Acosta et al. (2012) showed an effect on the expression of immune-related genes of Pacific oysters in the presence of diuron alone or mixed to other pesticides. The presence of pesticides could have a negative effect on the immune system of Pacific oysters decreasing immune capabilities, and a possible increase in susceptibility towards various infectious agents, including OsHV-1 could be observed. Further studies are needed in order to define interactions between Pacific oysters, OsHV-1 and the pesticides most frequently detected in the environment. It is also conceivable that the pesticides act directly on the virus itself. This may bring some answers about the complex relationships that may exist between environmental conditions and massive mortality outbreak of Pacific oysters. 


\section{Acknowledgments}

This work was partially funded through the EU project Bivalife $\left(n^{\circ}\right.$ 266157) and the Poitou Charentes

Region. The authors wish to thank the Ifremer hatchery team (LGPMM) in La Tremblade and the nursery team (LSPC) in Bouin for the production of Pacific oysters. 


\section{References}

Anderson, R. S. (1981). Effects of carcinogenic and non-carcinogenic environmental pollutants on immunological functions in marine invertebrates.Phyletic approaches to cancer. Japan Scientific Societies Press, Tokyo, 319-331.

Alvarez MR, Friedl FE. Effects of a fungicide on in vitro hemocyte viability, phagocytosis and attachment in the American oyster, Crassostrea virginica. Aquaculture. 1992 Oct 15;107(2-3):135-40.

Bates NS, Sutton NM, Campbell A. Suspected metaldehyde slug bait poisoning in dogs: a retrospective analysis of cases reported to the Veterinary Poisons Information Service. Vet Rec. 2012 Sep 29;171(13):324.

Bilan 2010 du réseau Corpep (2011) - Les pesticides dans les eaux superficielles bretonnes - Bretagne Environnement. http://www.bretagne-environnement.org/Media/Documentation/Bibliographies/Les-pesticidesdans-les-eaux-superficielles-bretonnes-bilan-2010-du-reseau-Corpep

Blakley B, Brousseau P, Fournier M, Voccia I. Immunotoxicity of pesticides: a review. Toxicology and Industrial Health. 1999 Feb 1;15(1-2):119-32.

Burgeot T., Gagnaire B., Renault C., Haure J., Moraga D., David D., Boutet I., Sauriau P.G., Malet N., Bouchet V., Le Roux A., Lapègue S. Bouilly K., Le Moullac G., Arzul G., Knoery J., Bacher C., Soletchnick P. (2008). Oyster summer mortality risks associated with environmental stress. Chapter 3 in Summer mortality of pacific oyster Crassostrea gigas. The Morest project. Edited by J.F. Samain and H. Combie. Quae Editions.107-153

Campbell A. Metaldehyde poisoning of dogs. Vet Rec. 2008 Sep 13;163(11):343.

Canty MN, Hagger JA, Moore RTB, Cooper L, Galloway TS. Sublethal impact of short term exposure to the organophosphate pesticide azamethiphos in the marine mollusc Mytilus edulis. Mar Pollut Bull. 2007 Apr;54(4):396-402.

Cheng TC. Bivalves. Invertebrate blood cells. 1981;(1):233-300.

Coles JA, Pipe RK. Phenoloxidase activity in the haemolymph and haemocytes of the marine mussel Mytilus edulis. Fish \& Shellfish Immunology. 1994 Sep;4(5):337-52.

Cooper EL, Roch P. Earthworm immunity: a model of immune competence. Pedobiologia. 2003 Jan;47(56):676-88.

Dai L, Wang W, Dong X, Hu R, Nan X. Molluscicidal activity of cardiac glycosides from Nerium indicum against Pomacea canaliculata and its implications for the mechanisms of toxicity. Environ Toxicol Pharmacol. 2011 Sep;32(2):226-32.

Dunier M, Siwicki AK, Demaël A. Effects of organophosphorus insecticides: Effects of trichlorfon and dichlorvos on the immune response of carp (Cyprinus carpio). Ecotoxicology and Environmental Safety. 1991 Aug;22(1):79-87.

Dunier M, Siwicki AK. Effects of pesticides and other organic pollutants in the aquatic environment on immunity of fish: a review. Fish \& Shellfish Immunology. 1993 Nov;3(6):423-38.

Gagnaire B, Renault T, Bouilly K, Lapegue S, Thomas-Guyon H. Study of atrazine effects on Pacific oyster, Crassostrea gigas, haemocytes. Curr Pharm Des. 2003;9(2):193-9.

Gagnaire B, Gay M, Huvet A, Daniel J-Y, Saulnier D, Renault T. Combination of a pesticide exposure and a bacterial challenge: In vivo effects on immune response of Pacific oyster, Crassostrea gigas (Thunberg). Aquatic Toxicology. 2007 août;84(1):92-102.

His E, Heyvang, Isabelle, Geffard Olivier, De Montaudouin Xavier. A COMPARISON BETWEEN OYSTER (CRASSOSTREA GIGAS) AND SEA URCHIN (PARACENTROTUS LIVIDUS) LARVAL BIOASSAYS FOR TOXICOLOGICAL STUDIES. 1999;

Jacquet R, Miège C, Bados P, Schiavone S, Coquery M. Evaluating the polar organic chemical integrative sampler for the monitoring of beta-blockers and hormones in wastewater treatment plant effluents and receiving surface waters. Environ Toxicol Chem. 2012 Feb;31(2):279-88.

Khakame SK, Wang X, Wu Y. Baseline toxicity of metaflumizone and lack of cross resistance between indoxacarb and metaflumizone in diamondback moth (Lepidoptera: Plutellidae). J Econ Entomol. 2013 Jun;106(3):1423-9.

Koner BC, Banerjee BD, Ray A. Organochlorine pesticide-induced oxidative stress and immune suppression in rats. Indian J Exp Biol. 1998 Apr;36(4):395-8. 
Koutros S, Berndt SI, Hughes Barry K, Andreotti G, Hoppin JA, Sandler DP, et al. Genetic susceptibility loci, pesticide exposure and prostate cancer risk. PLoS ONE. 2013;8(4):e58195.

Larson KG, Roberson BS, Hetrick FM. Effect of environmental pollutants on the chemiluminescence of hemocytes from the American oyster Crassostrea virginica. Diseases of aquatic organisms. 1989;6(2):131-6.

Luna-Acosta A, Renault T, Thomas-Guyon H, Faury N, Saulnier D, Budzinski H, et al. Detection of early effects of a single herbicide (diuron) and a mix of herbicides and pharmaceuticals (diuron, isoproturon, ibuprofen) on immunological parameters of Pacific oyster (Crassostrea gigas) spat. Chemosphere. 2012 Jun;87(11):1335-40.

Mills NJ. Metaldehyde poisoning of dogs. Vet Rec. 2008 Sep 6;163(10):310.

Moreau P, Burgeot T, Renault T. Pacific oyster (Crassostrea gigas) hemocyte are not affected by a mixture of pesticides in short-term in vitro assays. Environmental Science and Pollution Research. 2014 Apr;21(7):4940-9.

Nielsen, James W. "Method and composition for killing terrestrial molluscs." U.S. Patent No. 4,765,979. 23 Aug. 1988.

Renault T. Effects of Pesticides on Marine Bivalves: What Do We Know and What Do We Need to Know? In: Stoytcheva M, editor. Pesticides in the Modern World - Risks and Benefits [Internet]. InTech; 2011 [cited 2014 May 19]. Available from: http://www.intechopen.com/books/pesticides-in-themodern-world-risks-and-benefits/effects-of-pesticides-on-marine-bivalves-what-do-we-know-andwhat-do-we-need-to-know-

Russo J, Lagadic L. Effects of environmental concentrations of atrazine on hemocyte density and phagocytic activity in the pond snail Lymnaea stagnalis (Gastropoda, Pulmonata). Environ Pollut. 2004;127(2):303-11.

Segarra A, Pépin JF, Arzul I, Morga B, Faury N, Renault T. Detection and description of a particular Ostreid herpesvirus 1 genotype associated with massive mortality outbreaks of Pacific oysters, Crassostrea gigas, in France in 2008. Virus Res. 2010 Oct;153(1):92-9.

Snieszko SF. The effects of environmental stress on outbreaks of infectious diseases of fishes*. Journal of Fish Biology. 1974 Mar;6(2):197-208.

Tawde SN, Puschner B, Albin T, Stump S, Poppenga RH. Death by caffeine: presumptive malicious poisoning of a dog by incorporation in ground meat. J Med Toxicol. 2012 Dec;8(4):436-40.

Triebskorn R, Henderson I,F, Martin A, Kolher HR. Slugs as target or non-target organisms for environmental chemicals. 1996 In: Slugs and Snail Pests in Agriculture, ed, Henderson, I.F. BCPC Monograph No 66: 65-72

Wong, Steve, et al. "Environmental immunotoxicology." Animal biomarkers as pollution indicators. Springer Netherlands, 1992. 167-189.

Zhang H, Wang C, Lu H, Guan W, Ma Y. Residues and dissipation dynamics of molluscicide metaldehyde in cabbage and soil. Ecotoxicology and Environmental Safety. 2011 Sep;74(6):1653-8. 


\section{Figure legends}

Figure 1. Hemocyte activities tested after oyster exposure to metaldehyde at $1 \mathrm{X}$ concentration for family 32. (a) Cell size and complexity: pop 1 corresponds to a population of cells presenting large size and low complexity, pop 2 a population of large and complex cells, pop 3 a population of small and complex cells (granulocyte). (b) Pourcentage of non-specific esterase activities; Vertical-axis: number of cells; (pop 1) population considerated as negative cells; (pop 2) population of moderately stained cells; (pop 3) population of strongly stained cells. (c) Hemocyte mortality percentage after oyster exposure to metaldehyde for $24 \mathrm{~h}$. (d) Percentage of positive cells for phagocytic activity after oyster exposure to metaldehyde for $24 \mathrm{~h}$

Figure 2. Hemocyte activities tested after oyster exposure to metaldehyde at $1 \mathrm{X}$ concentration for family 29. (a) Cell size and complexity: pop 1 corresponds to a population of cells presenting large size and low complexity, pop 2 a population of large and complex cells, pop 3 a population of small and ucomplex cells (granulocyte). (b) Pourcentage of non-specific esterase activities; Verticalaxis: number of cells; (pop 1) population considerated as negative cells; (pop 2) population of moderately stained cells; (pop 3) population of strongly stained cells. (c) Hemocyte mortality percentage after oyster exposure to metaldehyde for $24 \mathrm{~h}$. (d) Percentage of positive cells for phagocytic activity after oyster exposure to metaldehyde for $24 \mathrm{~h}$. 
Figure 2 family 29

Cell size and complexity - family 29 (metaldehyde1X)

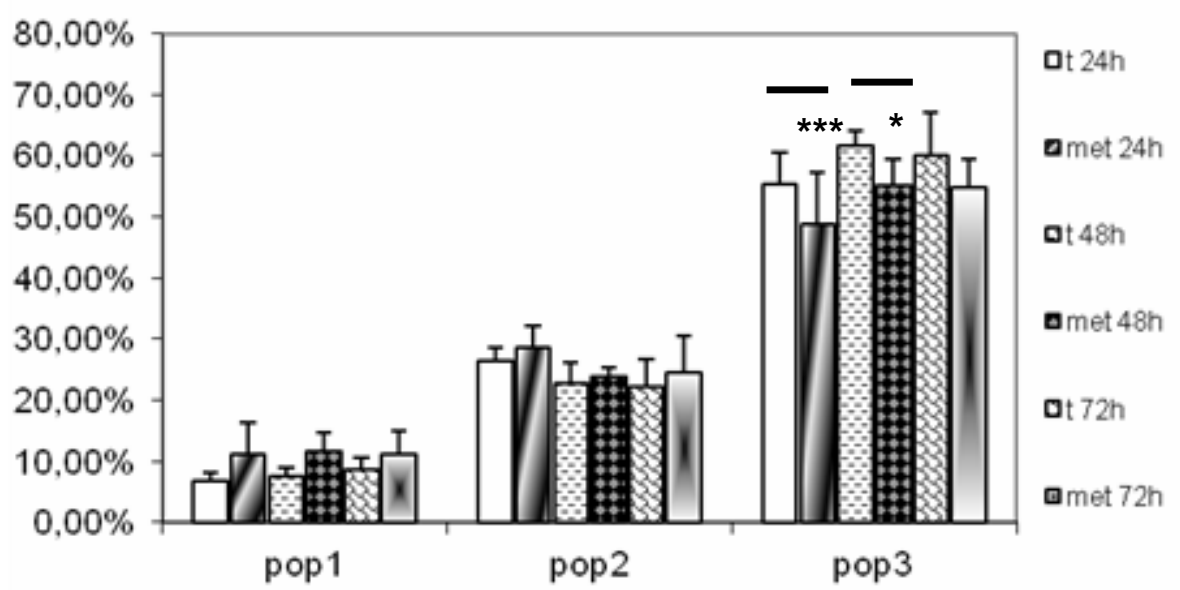

Hemocyte mortality - family 29 (metaldehyde 1X)

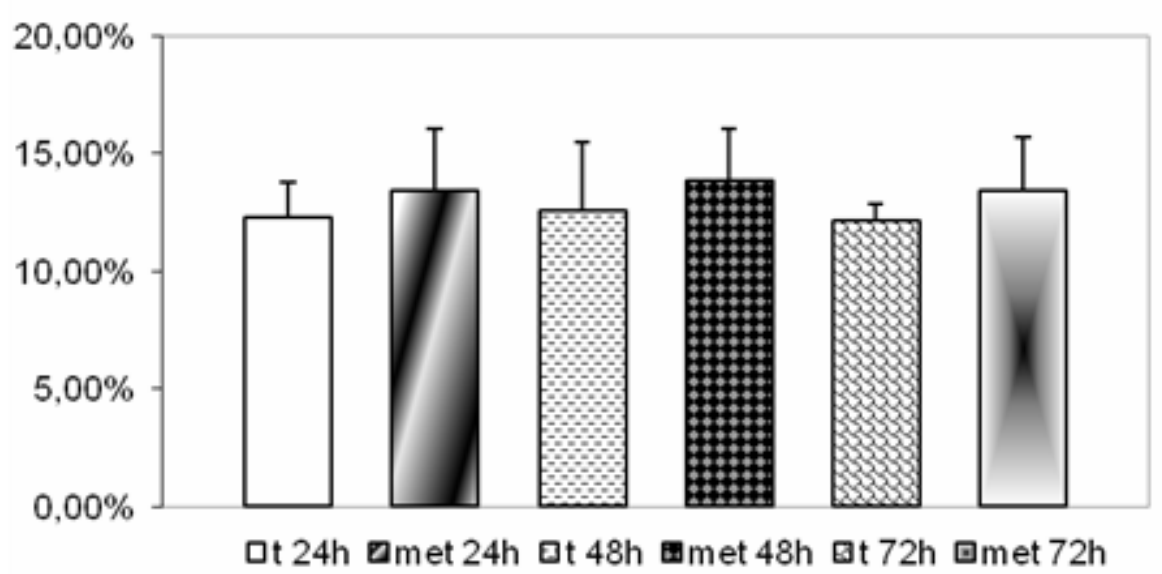

Non-specific esterase activities - family 29 (metaldehyde 1X)

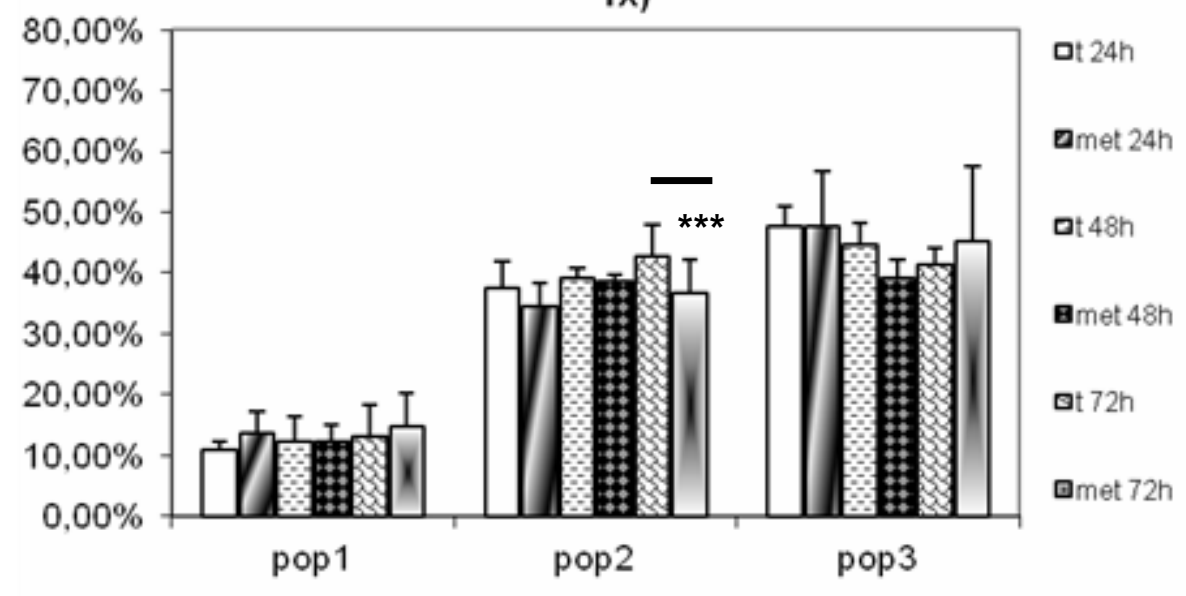

Phagocytic activity - family 29 (metaldehyde 1X)

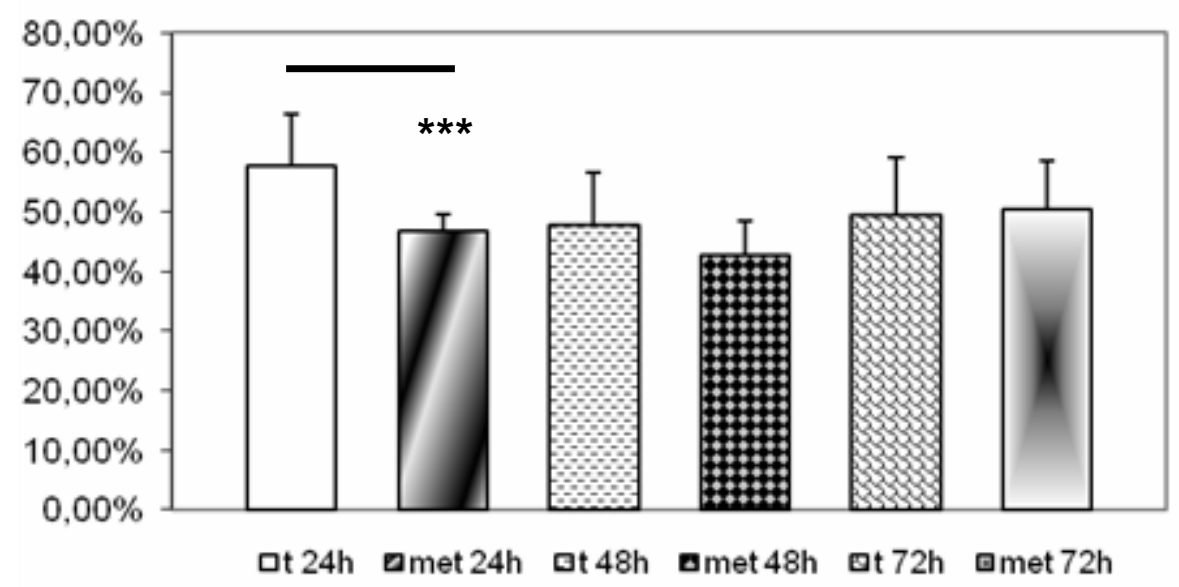

